Rio de Janeiro. Ano 10. Volume 17. Número 1. Janeiro a Junho de 2016

Periódico Semestral da Pós-Graduação Stricto Sensu em Direito Processual da UERJ

Patrono: José Carlos Barbosa Moreira. ISSN 1982-7636. pp. 7-26

http://www.e-publicacoes.uerj.br/index.php/redp/index

\title{
FUNDAMENTOS CONSTITUCIONAIS DA JURISDIÇÃO ${ }^{1}$
}

\section{CONSTITUTIONAL FOUNDATIONS OF JURISDICTION}

Alexandre Jamal Batista

Doutorando pela Pontifícia Universidade Católica de São Paulo - PUC/SP. Professor Universitário na Universidade Paulista - UNIP. Diretor de Comunicação do Instituto dos $\begin{array}{lllll}\text { Advogados de } & \text { São } & \text { Paulo } & \text { IASP. }\end{array}$ alexandre@ferrianiejamal.com.br

\section{Eduardo Fornazari Alencar}

Doutorando pela Pontifícia Universidade Católica de São Paulo - PUC/SP. Participou de Programa de Educação Continuada na Università degli Studi di Roma Tor Vergata em 2015. Professor Universitário na Universidade Paulista UNIP.

eduardofornazari@me.com

RESUMO: No atual estágio de nosso Estado de Direito não há como separar da Constituição Federal o estudo do direito processual civil, em especial o da jurisdição, visto que é na Lei Maior que se encontram presentes os fundamentos que a legitimam. No presente trabalho, são tratados os fundamentos constitucionais da jurisdição, tais como o princípio do juiz natural, princípio da inafastabilidade, princípio da imparcialidade, princípio da publicidade, princípio da motivação e princípio da submissão à coisa julgada. Conclui-se, afinal, que a jurisdição, como um dos baluartes do cidadão, encontra na "Constituição Cidadã” de 1988 os seus fundamentos e bases determinantes.

PALAVRAS-CHAVE: Constituição; Jurisdição; Fundamentos; Princípios; Processo.

\footnotetext{
${ }^{1}$ Artigo recebido em 17/04/2016 e aprovado em 31/05/2016.
} 
Revista Eletrônica de Direito Processual - REDP.

Rio de Janeiro. Ano 10. Volume 17. Número 1. Janeiro a Junho de 2016

Periódico Semestral da Pós-Graduação Stricto Sensu em Direito Processual da UERJ

Patrono: José Carlos Barbosa Moreira. ISSN 1982-7636. pp. 7-26

http://www.e-publicacoes.uerj.br/index.php/redp/index

ABSTRACT: At the current stage of our State of Law there is no way to separate the study of the civil procedural law from the Federal Constitution, especially the jurisdiction, because it is in the Constitution that there are the legitimizing foundations of the jurisdiction institute. In this article, we carry on about the constitutional foundations of jurisdiction, such as: the principle of natural justice, principle of access to justice, principle of impartiality, principle of publicity, principle of motivation and principle of submission to res judicata. The conclusion is, after all, that jurisdiction, as one of the bulwarks of the citizen, finds in the "Citizen Constitution" of 1988 its foundations and decisive bases.

KEYWORDS: Constitution; Jurisdiction; Foundations; Principles; Procedure.

\section{INTRODUÇÃO}

Não é raro ainda hoje o estudo dos diversos ramos do direito dissociado do estudo da Constituição Federal. Nelson Nery Junior ${ }^{2}$ atribui tal fato a um fenômeno cultural e político por que passou e tem passado o Brasil ao longo de sua história, qual seja, o de o país ter vivenciado no decorrer de sua existência poucos hiatos de tempo em regime democrático, em Estado de Direito. Como nossas Constituições não eram respeitadas, e muitas vezes sequer efetivamente aplicadas, pouca importância se atribuía ao Direito Constitucional.

No entanto, quando se vive em regime democrático, não há como separar o estudo de qualquer ramo do direito da Constituição Federal, principalmente em se tratando do direito processual civil, e em específico do estudo da jurisdição. ${ }^{3}$

\footnotetext{
${ }^{2}$ NERY JUNIOR, Nelson. Princípios do processo civil na Constituição Federal, p. 19.

3 "L'organizzazione e l'esercizio della giurisdizione civile sono regolati dalla legge (la legge sull'ordinamento giudiziario, il codice di procedura civile e alcune leggi speciali), ma anche la Costituzione contiene alcune norme importanti, dirette a garantire che il processo si svolga in modo 'équo', cioè con la possibilità per tutti gli interessati di far valere le loro regioni sia come attori, sia come convenuti." (LIEBMAN, Enrico Tullio. Manuale di diritto processuale civile, v. I, p. 7).
} 
Revista Eletrônica de Direito Processual - REDP.

Rio de Janeiro. Ano 10. Volume 17. Número 1. Janeiro a Junho de 2016

Periódico Semestral da Pós-Graduação Stricto Sensu em Direito Processual da UERJ

Patrono: José Carlos Barbosa Moreira. ISSN 1982-7636. pp. 7-26

http://www.e-publicacoes.uerj.br/index.php/redp/index

$\mathrm{O}$ professor Cândido Rangel Dinamarco ${ }^{4}$ denomina direito processual

constitucional, essa ênfase no estudo da ordem processual a partir dos princípios e garantias constitucionais, que leva em conta as recíprocas influências existentes entre a Constituição Federal e a ordem processual. ${ }^{5}$

Sendo a jurisdição exercício de poder do Estado soberano, e em se tratando de um Estado Democrático de Direito, não se pode deixar de examinar os fundamentos constitucionais da atividade jurisdicional, ou seja, os princípios presentes na Constituição Federal que legitimam a jurisdição no direito processual civil brasileiro ${ }^{6}$, o que é, enfim, o objetivo do presente trabalho.

A discussão da jurisdição a partir dos seus fundamentos constitucionais adquire ainda maior relevância com o advento recente da Lei $n^{\circ}$ 13.105/2015 que traz, em seu bojo, uma nova ordem processual ao sistema jurídico brasileiro.

\section{PRINCÍPIO DO JUIZ NATURAL}

Estabelece o art. $5^{\circ}$, da Constituição Federal, que "não haverá juízo ou tribunal de exceção" (inciso XXXVII) e que "ninguém será processado nem sentenciado senão pela autoridade competente" (inciso LIII). Esses dois incisos se complementam e revelam a adoção do princípio do juiz natural pela assembleia constituinte de 1988.

\footnotetext{
${ }^{4}$ A instrumentalidade do processo, p. 24 ss. e Instituições de direito processual civil, v. I, p. 53 e 188 ss. Confira-se também, nesse sentido: MESQUITA, Eduardo Melo de. As tutelas cautelar e antecipada, p. 133135.

${ }^{5}$ Calmon de Passos faz referência à constitucionalização do processo, novidade no campo do processo identificada na segunda metade do século XX, decorrência necessária dos "ganhos democráticos obtidos em termos de cidadania, que se traduziram em mais significativa participação nas decisões políticas de um maior número de instituições e pessoas. A noção de devido processo legal, já anteriormente trabalhada pela doutrina, ganhou dimensão nova, revestindo-se do caráter mais abrangente de garantia do devido processo constitucional." (Instrumentalidade do processo e devido processo legal, $\mathrm{n}^{\mathrm{o}} 12$ ).

${ }^{6}$ Não apenas do direito brasileiro a Constituição contém princípios que asseguram e legitimam a jurisdição, como se infere da lição de Couture: "Los textos constitucionales contienen abundantes previsiones para asegurar, en la medida en que la Constitución puede asegurar, el mejor desempeño de los órganos de la jurisdicción." (COUTURE, Eduardo J. Estudios de derecho procesal civil, t. 1, p. 84-85).
} 
Revista Eletrônica de Direito Processual - REDP.

Rio de Janeiro. Ano 10. Volume 17. Número 1. Janeiro a Junho de 2016

Periódico Semestral da Pós-Graduação Stricto Sensu em Direito Processual da UERJ

Patrono: José Carlos Barbosa Moreira. ISSN 1982-7636. pp. 7-26

http://www.e-publicacoes.uerj.br/index.php/redp/index

Decorre do referido princípio que apenas os órgãos criados pela Constituição

Federal poderão exercer atividade jurisdicional, sendo vedada a existência e a criação de órgãos jurisdicionais para julgar caso determinado, tenha o fato já ocorrido ou não.

A proibição dos tribunais de exceção permite que o jurisdicionado saiba de antemão quais são os órgãos responsáveis pela tutela jurisdicional caso ele viole direitos de outrem ou busque reparação de um direito lesado seu. ${ }^{7}$

A propósito, vale aqui destacar lição dos professores Luiz Alberto David Araújo e Vidal Serrano Nunes $\mathrm{Jr}^{8}$ que apontam ser o princípio do juiz natural ou do juiz legal um desdobramento da regra da igualdade, encerrando verdadeira vedação à discriminação de pessoas ou de casos para efeito de submissão a juízo ou tribunal que não o recorrente para todos os indivíduos.

Tribunal de exceção é aquele constituído por encomenda, criado ex post facto ou ad personam, fora dos quadros do Poder Judiciário, para julgar em determinado sentido, com parcialidade, prejudicando ou beneficiando alguém. Enquanto o juiz natural é aquele previsto abstratamente, o juízo de exceção é designado para atuar em determinado caso concreto ou individual. ${ }^{9}$

Não se confunda, entretanto, tribunal de exceção com justiças especializadas ou prerrogativas de foro. ${ }^{10}$

O poder do Estado é uno e indivisível, assim como o é a jurisdição enquanto forma de exercício desse poder. No entanto, para viabilizar o exercício desse poder foram criadas justiças especializadas, dividindo-se a atribuição da atividade jurisdicional entre

\footnotetext{
${ }^{7}$ Essa proibição de criação de juízes extraordinários deriva diretamente da Petition of Rights, de 1627, e do Bill of Rights, de 1688. (GRINOVER, Ada Pellegrini. O processo em sua unidade, 2, p. 5).

${ }^{8}$ Curso de Direito Constitucional, p. 235.

${ }^{9}$ Cf. PONTES DE MIRANDA, Francisco Cavalcanti. Comentários à Constituição de 1967 (com a Emenda $n^{\circ}$ 1, de 1969), t. V, p. 237-238; NERY JUNIOR, Nelson. Princípios do processo civil na Constituição Federal, p. 66 ss.; CARNEIRO, Athos Gusmão. Jurisdição e Competência, p. 11; e MESQUITA, Eduardo Melo de. As tutelas cautelar e antecipada, p. 72-73.

${ }^{10}$ Cf. PONTES DE MIRANDA. Op. cit., t. V, p. 237 ss.
} 
Revista Eletrônica de Direito Processual - REDP.

Rio de Janeiro. Ano 10. Volume 17. Número 1. Janeiro a Junho de 2016

Periódico Semestral da Pós-Graduação Stricto Sensu em Direito Processual da UERJ

Patrono: José Carlos Barbosa Moreira. ISSN 1982-7636. pp. 7-26

http://www.e-publicacoes.uerj.br/index.php/redp/index

diversos órgãos do Poder Judiciário. ${ }^{11}$ Essa divisão encontra raízes profundas no direito constitucional pátrio e no de quase todos os países, diante da impossibilidade de toda a atividade jurisdicional ser acumulada por um único órgão judicante. ${ }^{12}$

A prerrogativa de foro também se distingue por se tratar do favorecimento legal a alguém em razão de interesse público, como ocorre, dentre outros exemplos, com as ações de alimentos, cuja competência é do foro da residência do alimentando (cf. art. 53, II, do Novo Código de Processo Civil) e com as ações por responsabilidade do fornecedor de produtos e serviços, cuja competência é do foro do domicílio do autor (cf. art. 101, I, do Código de Defesa do Consumidor). ${ }^{13}$

Os foros de eleição também não ofendem o princípio do juiz natural, visto que constituídos por convenção das partes em matérias de competência relativa, dentro dos limites legais. Bem leciona o professor Nelson Nery Junior ${ }^{14}$ que o princípio do juiz natural aplica-se no processo civil somente às hipóteses de competência absoluta, já que é preceito de ordem pública.

Também não se pode considerar juiz natural o do lugar onde a causa deva ser julgada, uma vez que, segundo Giuseppe Sabatini ${ }^{15}$, natural é uma qualificação substancial do juiz, ou seja, é juiz natural aquele investido de competência material ou territorial pelas leis processuais e de organização judiciária. ${ }^{16}$

A convenção de arbitragem igualmente não ofende o princípio do juiz natural, pois por meio dela as partes optam por submeter seus litígios a solução de um juiz não togado. ${ }^{17}$

\footnotetext{
${ }^{11}$ Cf. NERY JUNIOR, Nelson. Op. cit., mesma página; e PONTES DE MIRANDA. Op. cit., t. V, p. 238.

${ }^{12}$ BASTOS, Celso Ribeiro. Comentários à Constituição do Brasil, v. 2, p. 204-205.

${ }^{13}$ Pode ser incluído dentre essas hipóteses também o exemplo da atividade jurisdicional desempenhada pelo Poder Legislativo, qual seja, a de julgar o Presidente da República por crimes de responsabilidade, cuja competência é do Senado Federal.

${ }^{14}$ Princípios do processo civil na Constituição Federal, p. 67.

15 "'Naturale' è, invece, un qualificazione sostanziale del giudice e, come tale, evidentemente non può coincidere con la qualificazione temporale della sua istituzione." (Principii costituzionali del processo penale, p.107).

${ }^{16}$ NERY JUNIOR, Nelson. Op. cit., p. 69 e MESQUITA, Eduardo Melo de. Op. cit., p. 70.

${ }^{17}$ Confira-se, nesse sentido: MESQUITA, Eduardo Melo de. Op. cit., p. 75.
} 
Revista Eletrônica de Direito Processual - REDP.

Rio de Janeiro. Ano 10. Volume 17. Número 1. Janeiro a Junho de 2016

Periódico Semestral da Pós-Graduação Stricto Sensu em Direito Processual da UERJ

Patrono: José Carlos Barbosa Moreira. ISSN 1982-7636. pp. 7-26

http://www.e-publicacoes.uerj.br/index.php/redp/index

No entanto, por se tratar de convenção entre partes capazes, bem como por ser permitida apenas a solução de conflitos que versem sobre direitos disponíveis, ficando afastadas questões de jurisdição voluntária, de família, de incapazes, falências ou outras que exijam participação do Ministério Público, a convenção de arbitragem está mais para um equivalente jurisdicional, como ocorre com a transação do que propriamente para a atividade jurisdicional em sentido estrito ${ }^{18}$. Da mesma forma compreende Couture ${ }^{19}$ ao afirmar que o árbitro não tem natureza jurisdicional em razão de carecer de poder de império, um dos atributos da jurisdição. Com efeito, a jurisdição é um dos atributos da soberania do Estado e, portanto, não pode ser delegada.

Decorre ainda do princípio do juiz natural o princípio da investidura, segundo o qual a jurisdição só pode ser exercida por quem dela se ache legalmente investido, isto é, regularmente investido na autoridade de juiz. ${ }^{20} \mathrm{E}$ na sistemática constitucional, “juízes são aqueles que, legalmente, ocupem os cargos nos juízos e tribunais, constitucionalmente previstos (CF, art. 92, I a VII), cujos cargos tenham sido legitimamente criados, pela legislação própria e infraconstitucional". ${ }^{21}$

\section{PRINCÍPIO DA INAFASTABILIDADE}

Dispõe o art. 5, XXXV, da Constituição Federal, que "a lei não excluirá da apreciação do Poder Judiciário lesão ou ameaça de direito". É desse dispositivo que se extrai o princípio da inafastabilidade ou princípio do controle jurisdicional ${ }^{22}$, segundo o qual todos têm garantia de acesso ao Poder Judiciário.

\footnotetext{
${ }^{18}$ O Novo Código de Processo Civil ratifica essa posição, de que a arbitragem não é atividade jurisdictional estrita, ao dispor no artigo $3^{\circ}$ que não se excuirá da apreciação jurisdictional lesão ou ameaça de direito, excetuando no $\S 1^{\circ}$ a possibilidade de se instalar a arbitragem por convenção das partes. Ora, se o parágrafo excetua a regra do caput, é porque o legislador também não considerou, na concepção do Código de Processo, a arbitragem como atividade jurisdictional.

19 "El juicio arbitral necesario tiene forma de proceso y órgano idóneo indicado por la ley, pero no tiene naturaleza jurisdiccional en razón de carecer los árbitros del imperium, que es uno de los atributos de la jurisdicción." (COUTURE, Eduardo J. Fundamentos del derecho procesal civil, p. 35).

${ }^{20}$ Cf. SANTOS, Moacyr Amaral. Primeiras linhas de direito processual civil, v. 1, p. 72; CINTRA, GRINOVER e DINAMARCO, Cândido Rangel. Teoria geral do processo, p. 135.

${ }^{21}$ ARRUDA ALVIM, José Manoel de. Manual de direito processual civil, v. 1, p. 164.

${ }^{22}$ CINTRA, GRINOVER e DINAMARCO. Teoria geral do processo, p. 138.
} 
Revista Eletrônica de Direito Processual - REDP.

Rio de Janeiro. Ano 10. Volume 17. Número 1. Janeiro a Junho de 2016

Periódico Semestral da Pós-Graduação Stricto Sensu em Direito Processual da UERJ

Patrono: José Carlos Barbosa Moreira. ISSN 1982-7636. pp. 7-26

http://www.e-publicacoes.uerj.br/index.php/redp/index

Da interpretação literal do mencionado dispositivo constitucional se poderia compreender ser o legislador o destinatário final da norma. No entanto, como bem adverte Nelson Nery Junior 23 , "o comando constitucional atinge a todos indistintamente, vale dizer, não pode o legislador e ninguém mais impedir que o jurisdicionado vá a juízo deduzir pretensão". E a Constituição Federal assegura a todos o acesso à justiça para postular tutela jurisdicional, preventiva ou reparatória, contemplando não apenas os direitos individuais, como também os difusos e coletivos.

Essa inafastabilidade do controle jurisdicional é também conhecida como princípio do direito de ação, como atesta o professor Nelson Nery Junior, mas não se confunde com o princípio processual da indeclinabilidade ${ }^{24}$, o qual não permite que o juiz se exima de sentenciar ou despachar alegando lacuna ou obscuridade do ordenamento jurídico (art. 140 do Novo Código de Processo Civil).

Marcelo Abelha Rodrigues ${ }^{25}$ afirma ser a norma do art. 126 do Código de Processo Civil de 1973 (hoje inscrita no supracitado art. 140 do Novo Código de Processo Civil) decorrência direta do princípio insculpido no art. $5^{\circ}, \mathrm{XXXV}$, da Constituição Federal. Concordamos com o autor nesse sentido, mas entendemos se tratar de dois distintos princípios: um de ordem constitucional, que diz respeito ao direito constitucional de ação; e outro infraconstitucional, que não permite ao juiz natural declinar da jurisdição alegando obscuridade ou lacuna legislativa.

Prossegue o professor Nelson Nery Junior ${ }^{26}$ lembrando que não se deve confundir o direito constitucional de ação com o direito de petição. Este é um direito político, impessoal e informal, que pode ser exercido por qualquer pessoa, física ou jurídica, mediante a notícia de ilegalidade ou abuso de poder ao órgão público destinatário, solicitando as providências cabíveis. Aquele é um direito público subjetivo e pessoal -

\footnotetext{
${ }^{23}$ NERY JUNIOR, Nelson. Op. cit., p. 94.

${ }^{24}$ Ibid., p. 107.

${ }^{25}$ Elementos de direito processual civil, p. 110.

${ }^{26}$ Op. cit., p. 97. Confira-se, no mesmo sentido: MESQUITA, Eduardo Melo de. As tutelas cautelar $e$ antecipada, p. $57 \mathrm{ss}$.
} 
Revista Eletrônica de Direito Processual - REDP.

Rio de Janeiro. Ano 10. Volume 17. Número 1. Janeiro a Junho de 2016

Periódico Semestral da Pós-Graduação Stricto Sensu em Direito Processual da UERJ

Patrono: José Carlos Barbosa Moreira. ISSN 1982-7636. pp. 7-26

http://www.e-publicacoes.uerj.br/index.php/redp/index

excetuados os direitos difusos e coletivos, onde os titulares são, respectivamente, indetermináveis e indeterminados - e que deve estar revestido de interesse processual, ou seja, o direito de ação deve preencher a condição da ação interesse processual.

Nesse sentido bem sintetiza João Batista Lopes $^{27}$, distinguindo o direito de ação do direito de petição, pelo fato de aquele consistir no "direito de obter um provimento jurisdicional de mérito", enquanto este tem um "conceito mais amplo, que abrange, além da simples movimentação da máquina judiciária, o direito de representação contra abusos ou irregularidades praticadas por autoridades e agentes públicos”.

Deve-se ter em mente, ainda, que o princípio da inafastabilidade, garantidor do direito constitucional de ação, não é ofendido pelas legítimas limitações existentes ao direito de ação.

Assim, para que o órgão jurisdicional se pronuncie quanto ao mérito da matéria posta sob sua apreciação, deverão estar preenchidas as condições da ação (Novo Código de Processo Civil, art. 485, VI) e presentes os pressupostos processuais (Novo Código de Processo Civil, art. 485, IV), além de ser observados os prazos e demais formais para a prática dos atos processuais. ${ }^{28}$

Não fere também o princípio da inafastabilidade a convenção de arbitragem, pois, como já mencionado ${ }^{29}$, apenas os direitos disponíveis podem ser objeto de convenção de arbitragem, e as partes, quando a celebram, estão optando por submeter o litígio à solução do árbitro.

Não é, portanto, “a lei” que exclui da apreciação do Poder Judiciário lesão ou ameaça de direito. A Lei 9.307/96 apenas faculta às partes a submissão de seus litígios ao juízo arbitral. Frise-se que não há, assim, qualquer derrogação à outorga dada pelo

\footnotetext{
${ }^{27}$ Ação declaratória, p. 28.

${ }^{28}$ Cf. NERY JUNIOR, Nelson. Princípios do processo civil na Constituição Federal, p. 99, e MESQUITA, Eduardo Melo de. Op. cit., p. 58.

${ }^{29}$ Ver item 1. Princípio do juiz natural, supra.
} 
Revista Eletrônica de Direito Processual - REDP.

Rio de Janeiro. Ano 10. Volume 17. Número 1. Janeiro a Junho de 2016

Periódico Semestral da Pós-Graduação Stricto Sensu em Direito Processual da UERJ

Patrono: José Carlos Barbosa Moreira. ISSN 1982-7636. pp. 7-26

http://www.e-publicacoes.uerj.br/index.php/redp/index

constituinte ao Poder Judiciário do monopólio da jurisdição. Este princípio persiste incólume e garantido.

\section{PRINCÍPIO DA IMPARCIALIDADE}

Também embasado em preceitos de ordem Constitucional, o princípio da imparcialidade é um dos fundamentos da jurisdição. Como se sabe, juristas de grande envergadura ${ }^{30}$ fizeram menção à imparcialidade ao formularem seus conceitos ou traçarem as características marcantes da atividade jurisdicional.

Se a jurisdição é exercício do poder soberano do Estado destinado a pacificar situações conflituosas com justiça, pode-se afirmar que apenas é possível falar em pacificação e justiça se tal atividade estiver revestida de imparcialidade.

Em razão dessa exigência, previu a Constituição Federal em seu art. 95 as garantias fundamentais de que os juízes devem gozar para o desempenho independente e imparcial da atividade jurisdicional. ${ }^{31}$

A primeira delas é a vitaliciedade, prevista no inciso I do mesmo artigo, que assegura ao magistrado sua permanência no cargo após dois anos de exercício da função, podendo perdê-lo apenas por sentença judicial transitada em julgado.

A segunda garantia, prevista no inciso II do dispositivo constitucional citado, é a inamovibilidade, que assegura ao magistrado sua permanência na vara ou juízo em que está julgando, salvo por remoção, disponibilidade ou aposentadoria por interesse público, que nesses casos deverão ser precedidas de decisão por voto de dois terços do tribunal competente, assegurada ao magistrado ampla defesa (art. 93, inciso VIII, da Constituição Federal).

\footnotetext{
${ }^{30}$ Cf. CINTRA, GRINOVER e DINAMARCO. Teoria Geral do Processo, p. 129; CAPPELLETTI, Mauro. Juizes legisladores?, trad. Carlos Alberto Alvaro de Oliveira, p. 74-75; SILVA, Ovídio A. Baptista da Silva. Curso de processo civil, v. 1, p. 40-41; e Teoria geral do processo civil, p. 74; MICHELI, Gian Antonio. Corso di diritto processuale civile, v. I, p. 6; e CALMON de PASSOS. Da jurisdição, p. 22.

${ }^{31}$ Cf. GRINOVER, Ada Pellegrini. O processo em sua unidade, 2, p. 46.
} 
Revista Eletrônica de Direito Processual - REDP.

Rio de Janeiro. Ano 10. Volume 17. Número 1. Janeiro a Junho de 2016

Periódico Semestral da Pós-Graduação Stricto Sensu em Direito Processual da UERJ

Patrono: José Carlos Barbosa Moreira. ISSN 1982-7636. pp. 7-26

http://www.e-publicacoes.uerj.br/index.php/redp/index

E, por fim, prevê a Constituição Federal no art. 95, III, a irredutibilidade de subsídios, com o objetivo de evitar qualquer espécie de chantagem, coação ou assédio que tenham o propósito de obter do magistrado um ato decisório parcial.

Decorre do princípio da imparcialidade o dever que tem o magistrado de assegurar às partes igualdade de tratamento (art. 139, I, do Novo Código de Processo Civil) e de se abster de suas funções quando considerado impedido (art. 144 do Novo Código de Processo Civil) ou suspeito (art. 145 do Novo Código de Processo Civil).

\section{PRINCÍPIOS DA PUBLICIDADE DOS ATOS PROCESSUAIS E DA MOTIVAÇÃO}

Também inerentes à jurisdição os princípios da publicidade dos atos processuais e da motivação.

É de conhecimento notório que a jurisdição exige que todos os seus atos sejam documentados, o que se faz por meio do processo. É, portanto, por via do processo que a jurisdição atua e se faz presente. ${ }^{32}$

Para atingir seu escopo, a jurisdição deve ser atuada publicamente, de modo que se garanta a imparcialidade dos atos jurisdicionais. Estabelece então a Constituição Federal que os julgamentos proferidos pelos órgãos do Poder Judiciário, em se tratando de atos processuais, devem ser públicos em respeito ao princípio da publicidade.

Essa é a razão pela qual a Constituição Federal fez constar em seu art. $5^{\circ}, \mathrm{LX}$, que "a lei só poderá restringir a publicidade dos atos processuais quando a defesa da intimidade ou o interesse social o exigirem", excetuando-se à regra geral hipóteses específicas. $^{33}$

\footnotetext{
${ }^{32}$ Cf. RODRIGUES, Marcelo Abelha. Op. cit., p. 112.

${ }^{33}$ Os artigos 11 e 189 do Novo Código de Processo Civil estabeleceram como regra a publicidade para os atos processuais em geral, não sendo inconstitucional a exceção nele prevista, para casos em que haja interesse
} 
Revista Eletrônica de Direito Processual - REDP.

Rio de Janeiro. Ano 10. Volume 17. Número 1. Janeiro a Junho de 2016

Periódico Semestral da Pós-Graduação Stricto Sensu em Direito Processual da UERJ

Patrono: José Carlos Barbosa Moreira. ISSN 1982-7636. pp. 7-26

http://www.e-publicacoes.uerj.br/index.php/redp/index

Em complemento ao princípio da publicidade dos atos processuais provém da Constituição Federal também o princípio da motivação, extraído de seu art. 93, IX: “todos os julgamentos dos órgãos do Poder Judiciário serão públicos, e fundamentadas todas as decisões, sob pena de nulidade, podendo a lei, se o interesse público exigir, limitar a presença, em determinados atos, às próprias partes e seus advogados, ou somente a estes".

José Carlos Barbosa Moreira ${ }^{34}$ leciona que a obrigatoriedade da fundamentação não é preceito recente em nosso ordenamento jurídico, encontrando raízes na tradição luso-brasileira, conforme dispunha no Código Filipino a Ordenação do Livro III, Título LXVI, § 7a , princípio: “E para as partes saberem se lhes convém apelar, ou agravar das sentenças definitivas, ou vir com embargos a elas, e os Juizes da mor alçada entenderem melhor os fundamentos, por que os Juizes inferiores se movem a condenar, ou absolver, mandamos que todos nossos Desembargadores, e quaisquer outros Julgadores, ora sejam Letrados, ora o não sejam, declarem especificamente em suas sentenças definitivas, assim na primeira instância, como no caso de apelação, ou agravo, ou revista, as causas, em que se fundaram a condenar, ou absolver, ou a confirmar, ou revogar".

Prossegue o jurista lembrando que no Brasil já independente, por portaria de 31 de março de 1824 os juízes eram lembrados do dever de fundamentar seus decisórios. Tal princípio inspirou também o art. 232 do Decreto $\mathrm{n}^{\mathrm{o}} 737$ de $1850^{35}$ : “A sentença deve ser clara, sumariando o juiz o pedido e a contestação com os fundamentos respectivos, motivando com precisão o seu julgado, e declarando sob sua responsabilidade a lei, uso ou estilo em que se funda".

público, digam respeito a casamento, filiação, separação de cônjuges, conversão desta em divórcio, alimentos e guarda de menores, visto que em consonância com a restrição facultada pela Constituição Federal.

${ }^{34}$ BARBOSA MOREIRA, José Carlos. A motivação das decisões judiciais como garantia inerente ao estado de direito, in Temas de direito processual: segunda série, p. 85.

${ }^{35}$ O "Regulamento baixado com o Decreto $\mathrm{n}^{\circ} 737$, de 25 de novembro de 1850 ", ou "Regulamento $\mathrm{n}^{\circ} 737$ ", como, sinteticamente, passou para a posteridade, foi o primeiro diploma processual brasileiro a vigorar em todo o País. Aplicado inicialmente às causas comerciais, uma vez que, pelo ato, o Imperador Dom Pedro II cumpriu o que dispunha o art. 27 do Código Comercial vigente, estendeu-se tempos depois às causas civis, por força do Decreto $\mathrm{n}^{\circ} 3.272$, de 5 de outubro de 1885. (LIMA, Alcides de Mendonça. Comentários ao Código de Processo Civil, v. VI, p. 33-34). 
Revista Eletrônica de Direito Processual - REDP.

Rio de Janeiro. Ano 10. Volume 17. Número 1. Janeiro a Junho de 2016

Periódico Semestral da Pós-Graduação Stricto Sensu em Direito Processual da UERJ

Patrono: José Carlos Barbosa Moreira. ISSN 1982-7636. pp. 7-26

http://www.e-publicacoes.uerj.br/index.php/redp/index

$\mathrm{O}$ principio da motivação, portanto, diz respeito à necessidade de

fundamentação de todas as decisões proferidas pelos órgãos jurisdicionais, sob pena de nulidade. Independentemente de ter sido referida expressamente pelo legislador constituinte, a obrigatoriedade de fundamentação das decisões judiciais surge, antes de tudo, como garantia do Estado de Direito. ${ }^{36}$

O Novo Código de Processo Civil, já vigente, reafirma a norma constitucional ao dispor em seu art. 371 que "o juiz apreciará a prova constante dos autos, independentemente do sujeito que tiver promovido, e indicará na decisão as razões da formação do seu convencimento". Também seu art. 489, II, traz como elementos essenciais da sentença os fundamentos de fato e de direito em que se baseou o juiz para decidir a causa; e o $\S 1^{\circ}$ do art. 489 estende a regra também às demais decisões judiciais, inclusive os acórdãos e até mesmo as decisões interlocutórias, impondo de forma minuciosa a necessidade de fundamentação.

A necessidade de fundamentação das sentenças judiciais pode ser analisada sob diferentes aspectos, como expõe José Rogério Cruz e Tucci ${ }^{37}$, que vão desde a reconstrução histórica dos fatos pertinentes a determinada situação concreta, passando pela necessidade de comunicação judicial, pelo exercício de lógica, pela atividade críticointelectual do juiz, até a sua submissão, como ato processual, ao Estado de Direito e às garantias constitucionais gravadas no art. $5^{\circ}$ da Constituição Federal.

Fundamentar quer dizer lançar os fundamentos, fundar. Fundamentos esses que devem dizer respeito às razões de fato e de direito que convenceram o julgador a decidir determinada questão neste ou naquele sentido; tem, pois, implicação substancial e não meramente formal. ${ }^{38}$

A ausência de fundamentação acarreta a nulidade das decisões judiciais. Assim, nulas são algumas decisões que indeferem pretensões sob a argumentação de

\footnotetext{
${ }^{36}$ BARBOSA MOREIRA, José Carlos. Op. cit., p. 88 ss.

${ }^{37}$ Cf. CRUZ e TUCCI, José Rogério. A motivação da sentença no processo civil, p. $11 \mathrm{ss.}$

${ }^{38}$ NERY JUNIOR, Nelson. Princípios do processo civil na Constituição Federal, p. 176.
} 
Revista Eletrônica de Direito Processual - REDP.

Rio de Janeiro. Ano 10. Volume 17. Número 1. Janeiro a Junho de 2016

Periódico Semestral da Pós-Graduação Stricto Sensu em Direito Processual da UERJ

Patrono: José Carlos Barbosa Moreira. ISSN 1982-7636. pp. 7-26

http://www.e-publicacoes.uerj.br/index.php/redp/index

ausência ou falta de amparo legal, bem como outras que concedem a providência deduzida por estarem presentes os pressupostos legais. O art. 489, $\S 1^{\circ}$, do Novo Código de Processo Civil $^{39}$ trata da questão, hoje, de forma bem pormenorizada. A fundamentação diz respeito à compreensão e interpretação dos fatos e do direito por parte do julgador, que deve necessariamente, repita-se, sob pena de nulidade, externar no decisório os motivos pelos quais considera presentes ou ausentes os pressupostos legais naquele caso concreto.

Pondera o professor Nelson Nery Junior ${ }^{40}$ que, de ordinário, a Constituição Federal não contém norma sancionadora, sendo simplesmente descritiva e principiológica, afirmando direitos e impondo deveres. No entanto, tamanha a gravidade da ausência de motivação, que o legislador constituinte, afastando-se da melhor técnica, cominou no próprio texto constitucional a pena de nulidade.

\section{PRINCÍPIO DA SUBMISSÃO À COISA JULGADA}

Nos termos do art. $6^{\circ}, \S 3^{\circ}$, da Lei de Introdução às Normas do Direito Brasileiro, "chama-se coisa julgada ou caso julgado a decisão judicial de que já não caiba mais recurso". Também estabelece o art. 502 do Novo Código de Processo Civil que coisa julgada material é "a autoridade que torna imutável e indiscutível a decisão de mérito não mais sujeita a recurso". Na doutrina de Couture ${ }^{41}$, é a autoridade e eficácia de uma sentença judicial, quando não existem contra ela meios de impugnação que permitam modificá-la.

\footnotetext{
${ }^{39}$ Art. 489. (...)

$\S 1^{\circ}$ Não se considera fundamentada qualquer decisão judicial, seja ela interlocutória, sentença ou acórdão, que:

I - se limitar à indicação, à reprodução ou à paráfrase de ato normativo, sem explicar sua relação com a causa ou a questão decidida;

II - empregar conceitos jurídicos indeterminados, sem explicar o motivo concreto de sua incidência no caso; III - invocar motivos que se prestariam a justificar qualquer outra decisão;

IV - não enfrentar todos os argumentos deduzidos no processo capazes de, em tese, infirmar a conclusão adotada pelo julgador;

$\mathrm{V}$ - se limitar a invocar precedente ou enunciado de súmula, sem identificar seus fundamentos determinantes nem demonstrar que o caso sob julgamento se ajusta àqueles fundamentos;

VI - deixar de seguir enunciado de súmula, jurisprudência ou precedente invocado pela parte, sem demonstrar a existência de distinção no caso em julgamento ou a superação do entendimento.

${ }^{40}$ Ibid., p. 177.

${ }^{41}$ COUTURE, Eduardo J. Fundamentos del derecho procesal civil, p. 401.
} 
Revista Eletrônica de Direito Processual - REDP.

Rio de Janeiro. Ano 10. Volume 17. Número 1. Janeiro a Junho de 2016

Periódico Semestral da Pós-Graduação Stricto Sensu em Direito Processual da UERJ

Patrono: José Carlos Barbosa Moreira. ISSN 1982-7636. pp. 7-26

http://www.e-publicacoes.uerj.br/index.php/redp/index

Celso $\mathrm{Neves}^{42}$, em exímio trabalho elaborado por ocasião de sua cátedra na

Faculdade de Direito da Universidade de São Paulo, depois de percorrer a doutrina de insignes juristas brasileiros e estrangeiros, assegura que "o conceito de coisa julgada que prevalece na doutrina brasileira é o de Liebman que, como assinala Jorge Salomão, mereceu acolhida no Anteprojeto do Prof. Alfredo Buzaid”.

Por sua vez, Liebman ${ }^{43}$ distingue a eficácia da sentença de sua imutabilidade, sintetizando que, em verdade, a coisa julgada não é um efeito das sentenças, mas sim uma qualidade, de imutabilidade, de que podem revestir-se todos os efeitos da sentença, quaisquer que sejam eles (condenatório, constitutivo ou declaratório).

A doutrina ${ }^{44}$, de modo geral, é convergente ao considerar a coisa julgada uma característica própria da jurisdição. E de fato, é um atributo peculiar da jurisdição, visto que nem a legislação nem a administração podem reunir nos atos que expedem as características de irreversibilidade, imutabilidade e coercibilidade. Pela própria natureza, as leis podem ser revogadas por outras leis e os atos administrativos são revogados ou são modificados por outros atos. ${ }^{45}$

Essa particularidade da jurisdição está diretamente relacionada com seus escopos, pois é a coisa julgada que traz segurança e estabilidade jurídica para as situações conflituosas pacificadas por meio da atividade jurisdicional. Sem segurança e estabilidade não se há de cogitar pacificação social. ${ }^{46}$

\footnotetext{
${ }^{42}$ NEVES, Celso. Coisa julgada civil, p. 317.

${ }^{43}$ Cf. LIEBMAN, Enrico Tullio. Eficácia e Autoridade da Sentença, trad. Alfredo Buzaid e Benvindo Aires, p. 50-55.

${ }^{44}$ Cf. LA CHINA, Sergio. Diritto processuale civile, p. 131-136; ALMEIDA JÚNIOR, João Mendes de. Direito judiciário brasileiro, p. 34; MARQUES, José Frederico. Instituições de direito processual civil, v. I, p. 226; CARNEIRO, Athos Gusmão. Jurisdição e competência, p. 22; OLIVEIRA JÚNIOR, Waldemar Mariz de. Curso de direito processual civil, v. I, p. 101; GRECO FILHO, Vicente. Direito processual civil brasileiro, v. 1, p. 168; CARREIRA ALVIM, José Eduardo. Elementos de teoria geral do processo, p. 65-74.

${ }^{45}$ COUTURE, Eduardo J. Op. cit., p. 412.

${ }^{46}$ De certo modo trata-se da "imunização", expressão empregada por Cândido Rangel Dinamarco ao abordar os escopos políticos da jurisdição. Para o jurista, imunização é a inadmissibilidade de revisão daquilo que o Estado decidiu soberanamente e impôs imperativamente (A instrumentalidade do processo, p. 168-171).
} 
Revista Eletrônica de Direito Processual - REDP.

Rio de Janeiro. Ano 10. Volume 17. Número 1. Janeiro a Junho de 2016

Periódico Semestral da Pós-Graduação Stricto Sensu em Direito Processual da UERJ

Patrono: José Carlos Barbosa Moreira. ISSN 1982-7636. pp. 7-26

http://www.e-publicacoes.uerj.br/index.php/redp/index

Eis a razão pela qual a Constituição Federal assegurou, em seu art. $5^{\circ}$,

XXXVI, que "a lei não prejudicará o direito adquirido, o ato jurídico perfeito e a coisa julgada", norma que é trazida também na Lei de Introdução às Normas do Direito Brasileiro, em seu art. $6^{\circ}$ : "a lei em vigor terá efeito imediato e geral, respeitados o ato jurídico perfeito, o direito adquirido e a coisa julgada".

Couture $^{47}$, ao estabelecer o conteúdo da jurisdição, afirma se tratar da existência de um conflito cuja relevância jurídica exige uma solução com decisão suscetível de adquirir autoridade de coisa julgada. E enfatiza: "a coisa julgada pertence à essência da jurisdição. Se o ato não adquire real e eventualmente autoridade de coisa julgada, não é jurisdicional. Se um ato adquire autoridade de coisa julgada, é jurisdicional. Não há jurisdição sem autoridade de coisa julgada”.

O fato de a coisa julgada ser atributo da jurisdição, que a diferencia da legislação e da administração, não implica afirmar, como o fez Couture, que "não há jurisdição sem autoridade de coisa julgada", ou o inverso, "não há coisa julgada sem jurisdição”.

A coisa julgada é atributo da jurisdição garantido constitucionalmente para, como já se afirmou, atribuir segurança e estabilidade às situações conflituosas pacificadas. No entanto, não se pode negar que há atividade jurisdicional com pronunciamento decisório sem força de coisa julgada material, podendo, portanto, ser modificado por circunstâncias supervenientes que lhe alterem no estado de fato e de direito, a exemplo do que estabelece o art. 505, I, do Novo Código de Processo Civil ${ }^{48}$ nas relações jurídicas de trato continuado; como também há decisões proferidas fora do âmbito jurisdicional que, por disposição legal,

\footnotetext{
47 "La cosa juzgada pertenece a la esencia de la jurisdicción. Si el acto no adquiere real o eventualmente autoridad de cosa juzgada, no es jurisdiccional. Si un acto adquiere autoridad de cosa juzgada es jurisdiccional. No hay jurisdicción sin autoridad de cosa juzgada." (COUTURE, Eduardo J. Op. cit., p. 36).

${ }^{48}$ Art. 505. Nenhum juiz decidirá novamente questões já decididas relativas à mesma lide, salvo:

- se, tratando-se de relação jurídica de trato continuado, sobreveio modificaçào no estado de fato ou de direito, caso em que poderá a parte pedir a revisão do que foi estatuído na sentença.
} 
Revista Eletrônica de Direito Processual - REDP.

Rio de Janeiro. Ano 10. Volume 17. Número 1. Janeiro a Junho de 2016

Periódico Semestral da Pós-Graduação Stricto Sensu em Direito Processual da UERJ

Patrono: José Carlos Barbosa Moreira. ISSN 1982-7636. pp. 7-26

http://www.e-publicacoes.uerj.br/index.php/redp/index

têm força de coisa julgada, como ocorre na arbitragem, nos termos do art. 31 da Lei $9.307 / 96^{49}$.

Assim, embora a coisa julgada seja atributo da jurisdição e a diferencie dos demais poderes estatais, não se pode afirmar que ela é atributo exclusivo da jurisdição, nem que sem coisa julgada não há atividade jurisdicional.

Como bem leciona José de Albuquerque Rocha ${ }^{50}$, "na verdade a coisa julgada não é característica da jurisdição, como diz uma corrente do pensamento jurídico-processual, mas um mecanismo funcional à jurisdição, no sentido de que serve para garantir a finalidade a que se destina a atividade jurisdicional (...) Por outras palavras, para que a jurisdição possa atingir seu fim, de encerrar o processo de efetivação do direito, é necessário que as normas jurisdicionais gozem de uma grande estabilidade (coisa julgada) porque se pudessem ser revogadas facilmente isto frustraria sua finalidade."

Como instrumento capaz de assegurar a irreversibilidade e a imutabilidade das decisões jurisdicionais, pode-se afirmar que a coisa julgada material está diretamente relacionada, sim, à solução do mérito dos litígios, dos conflitos de interesses, vez que, sem ela, não se poderia considerar pacificada a situação submetida a julgamento, pois ainda estaria passível de ser modificada ou revertida.

No entanto, a atividade jurisdicional não se presta apenas à solução de litígios ou conflitos de interesses, sendo mais abrangentes seus escopos ${ }^{51}$.

\section{CONCLUSÃO}

No atual estágio de nosso Estado de Direito, não há como separar da Constituição Federal o estudo do Direito Processual Civil, em especial o da jurisdição, visto que é na Lei Magna que se encontram presentes os fundamentos que a legitimam.

\footnotetext{
${ }^{49}$ Art. 31. A sentença arbitral produz, entre as partes e seus sucessores, os mesmos efeitos da sentença proferida pelos órgãos do Poder Judiciário e, sendo condenatória, constitui título executivo.

${ }^{50}$ Estudos sobre o Poder Judiciário, p. 24.

${ }^{51}$ Além do escopo jurídico, a jurisdição tem também escopos sociais e politicos.
} 
Revista Eletrônica de Direito Processual - REDP.

Rio de Janeiro. Ano 10. Volume 17. Número 1. Janeiro a Junho de 2016

Periódico Semestral da Pós-Graduação Stricto Sensu em Direito Processual da UERJ

Patrono: José Carlos Barbosa Moreira. ISSN 1982-7636. pp. 7-26

http://www.e-publicacoes.uerj.br/index.php/redp/index

Em apertada síntese, os pilares e fundamentos constitucionais da jurisdição, tratados ao longo desse trabalho, podem assim ser elencados:

- princípio do juiz natural: princípio este que, de um lado, assegura que apenas órgãos criados pela Constituição Federal podem exercer atividade jurisdicional, e, de outro, veda a existência ou criação de órgãos jurisdicionais para julgar caso determinado, tenha o fato já ocorrido ou não. Não se pode, no entanto, confundir isso que se denomina de tribunal de exceção, com as justiças especializadas e com as hipóteses de prerrogativas de foro.

- princípio da inafastabilidade: princípio que é destinado a todos indistintamente e que garante o intitulado direito de ação, ou seja, o acesso à justiça para postular tutela jurisdicional, preventiva ou reparatória, contemplando não apenas os direitos individuais, como também os difusos e coletivos. Mas esse direito de ação não se limita ao chamado direito de petição, que, sabidamente, é mais restrito do que aquele.

- princípio da imparcialidade: princípio que garante a todos o direito a um juízo que seja imparcial e independente. Para tanto, os juízes devem ser dotados das prerrogativas de vitaliciedade, de inamovibilidade e também de irredutibilidade de subsídios. Decorre, ainda, de referido fundamento, o dever que tem o magistrado de assegurar às partes igualdade de tratamento e de se abster de suas funções quando houver situação de impedimento ou suspeição.

- princípio da publicidade dos atos processuais: princípio segundo o qual se pode entender que a jurisdição, até mesmo para atingir seu objetivo e garantir a imparcialidade dos atos jurisdicionais, deve ser atuada publicamente, impondo, como regra, a publicidade dos atos processuais. Esta garantia só poderá ser restringida em situações excepcionais e específicas, quando a defesa da intimidade ou o interesse social assim o exigirem.

- princípio da motivação: princípio constitucional que vem de longa tradição lusobrasileira, que encerra verdadeira garantia do Estado de Direito e que diz respeito à obrigatoriedade de fundamentação de todas as decisões judiciais, sob pena de nulidade. 
Revista Eletrônica de Direito Processual - REDP.

Rio de Janeiro. Ano 10. Volume 17. Número 1. Janeiro a Junho de 2016

Periódico Semestral da Pós-Graduação Stricto Sensu em Direito Processual da UERJ

Patrono: José Carlos Barbosa Moreira. ISSN 1982-7636. pp. 7-26

http://www.e-publicacoes.uerj.br/index.php/redp/index

Aliás, não por outras razões, o Novo Código de Processo Civil, fazendo coro ao princípio aqui examinado, traz ainda com maior enfoque a imprescindibilidade da fundamentação de fato e de direito como elemento essencial da prestação jurisdicional.

- princípio da submissão à coisa julgada: princípio que traça uma particularidade da jurisdição, particularidade essa relacionada com seus escopos, no caso, a observância à coisa julgada que, por sua vez, cauciona segurança e estabilidade nas relações jurídicas, sem o que, como já se disse alhures, não se pode conceber um ideal de pacificação social.

A jurisdição se traduz, na verdade, como um dos baluartes do cidadão. A Constituição Federal de 1988, reconhecidamente tida como a "Constituição Cidadã", não poderia, evidentemente, deixar de contemplar em seu bojo os fundamentos e as bases desse bastião dos cidadãos brasileiros. O presente trabalho se dispôs singelamente a tratar desses fundamentos e dar alguma contribuição a todos os que, de algum modo, tenham interesse no assunto.

\section{REFERÊNCIAS BIBLIOGRÁFICAS:}

ALMEIDA JÚNIOR, João Mendes de. Direito judiciário brasileiro. 4. ed. Rio de JaneiroSão Paulo: Freitas Bastos, 1954.

ARAÚJO, Luiz Alberto David; NUNES JÚNIOR, Vidal Serrano. Curso de Direito Constitucional. 17. ed. - São Paulo: Editora Verbatim, 2013.

ARRUDA ALVIM, José Manoel de. Manual de direito processual civil. 6. ed. São Paulo: Revista dos Tribunais, 1997. v. 1.

BASTOS, Celso Ribeiro. Comentários à Constituição do Brasil: promulgada em 5 de outubro de 1988. São Paulo: Saraiva, 1989. v. 2.

CAPPELLETTI, Mauro. Juizes legisladores? Trad. Carlos Alberto Alvaro de Oliveira. Porto Alegre: Fabris, 1993.

CARNEIRO, Athos Gusmão. Jurisdição e competência: exposição didática: área do direito processual civil. 11. ed. São Paulo: Saraiva, 2001.

CARREIRA ALVIM, José Eduardo. Elementos de teoria geral do processo. 3. ed. Rio de Janeiro: Forense, 1995. 
Revista Eletrônica de Direito Processual - REDP.

Rio de Janeiro. Ano 10. Volume 17. Número 1. Janeiro a Junho de 2016

Periódico Semestral da Pós-Graduação Stricto Sensu em Direito Processual da UERJ

Patrono: José Carlos Barbosa Moreira. ISSN 1982-7636. pp. 7-26

http://www.e-publicacoes.uerj.br/index.php/redp/index

CINTRA, Antônio Carlos de Araújo; GRINOVER, Ada Pellegrini; DINAMARCO, Cândido

Rangel. Teoria geral do processo. 12. ed. São Paulo: Malheiros, 1996.

COUTURE, Eduardo J. Estudios de derecho procesal civil. 3. ed. Buenos Aires: Depalma, 1998. t. I.

Fundamentos del derecho procesal civil. 3. ed. Buenos Aires: Depalma, 1997.

CURIA, Luiz Roberto; CÉSPEDES, Lívia; ROCHA, Fabiana Dias da. Códigos de processo civil comparados. São Paulo: Saraiva, 2015.

DINAMARCO, Cândido Rangel. A instrumentalidade do processo. 6. ed. São Paulo: Malheiros, 1998.

GRECO FILHO, Vicente. Direito processual civil brasileiro. 15. ed. São Paulo: Saraiva, 2000. v. 1.

GRINOVER, Ada Pellegrini. O processo em sua unidade, 2. 1. ed. Rio de Janeiro, Forense, 1984.

LA CHINA, Sergio. Diritto processuale civile. Milano: Giuffrè, 1991.

LIEBMAN, Enrico Tullio. Manuale di diritto processuale civile. 4. ed. Milano: Giuffrè, 1984. v. I.

. Eficácia e autoridade da sentença. Trad. Alfredo Buzaid e Benvindo Aires; trad. dos textos posteriores à edição de 1945 e notas relativas ao direito brasileiro vigente de Ada Pellegrini Grinover. 3. ed. Rio de Janeiro: Forense, 1984.

LIMA, Alcides de Mendonça. Comentários ao Código de Processo Civil, lei $n^{\circ} 5.869$, de 11 de janeiro de 1973. 5. ed. Rio de Janeiro: Forense, 1997. v. VI.

LOBO DA COSTA, Moacyr. A revogação da sentença: gênese e genealogia. São Paulo: Ícone, 1995.

LOPES, João Batista. Ação declaratória. 3. ed. São Paulo: Revista dos Tribunais, 1991.

MARQUES, José Frederico. Instituições de direito processual civil. 3. ed. Rio de Janeiro: Forense, 1971. v. 5.

MESQUITA, Eduardo Melo de. As tutelas cautelar e antecipada. São Paulo: Revista dos Tribunais, 2002.

MICHELI, Gian Antonio. Corso di diritto processuale civile. Milano: Giuffrè, 1959. v. 1.

MOREIRA, José Carlos Barbosa. A motivação das decisões judiciais como garantia inerente ao Estado de Direito. In: Temas de direito processual: segunda série. São Paulo: Saraiva, 1980. p. 83-95. 
Revista Eletrônica de Direito Processual - REDP.

Rio de Janeiro. Ano 10. Volume 17. Número 1. Janeiro a Junho de 2016

Periódico Semestral da Pós-Graduação Stricto Sensu em Direito Processual da UERJ

Patrono: José Carlos Barbosa Moreira. ISSN 1982-7636. pp. 7-26

http://www.e-publicacoes.uerj.br/index.php/redp/index

NERY JUNIOR, Nelson. Princípios do processo civil na Constituição Federal. 6. ed. São

Paulo: Revista dos Tribunais, 2000.

NEVES, Celso. Coisa julgada civil. São Paulo: Revista dos Tribunais, 1971.

OLIVEIRA JÚNIOR, Waldemar Mariz de. Curso de direito processual civil: teoria geral do processo civil. São Paulo: Revista dos Tribunais, 1968. v. 1.

PASSOS, José Joaquim Calmon de. Da jurisdição. Salvador: [s.n.], 1957.

. Instrumentalidade do processo e devido processo legal. In: Jus Navigandi, n. 58.

[Internet] http://www1.jus.com.br/doutrina/texto.asp?id=3062 [Capturado 25.Set.2002].

PONTES DE MIRANDA, Francisco Cavalcanti. Comentários à Constituição de 1967 (com a Emenda $n^{\circ}$ 1, de 1969). 2. ed. São Paulo: Revista dos Tribunais, 1971. t. V.

ROCHA, José de Albuquerque. Estudos sobre o Poder Judiciário. São Paulo, Malheiros, 1995.

RODRIGUES, Marcelo Abelha. Elementos de direito processual civil. São Paulo: Revista dos Tribunais, 1998.

SABATINI, Giuseppe. Principii costituzionali del processo penale. Napoli: Eugenio Jovene, 1976.

SANTOS, Moacyr Amaral. Primeiras linhas de direito processual civil. 21. ed. São Paulo:

Saraiva, 1999. v. 1.

SILVA, Ovídio Araújo Baptista da. Curso de processo civil: processo de conhecimento. 4. ed. São Paulo: Revista dos Tribunais, 1998. v. 1.

; GOMES, Fábio. Teoria geral do processo civil. 3. ed. ver. e atual. São Paulo: Revista dos Tribunais, 2002.

TUCCI, José Rogério Cruz e. A motivação da sentença no processo civil. São Paulo: Saraiva, 1987. 